\title{
Peripheral vascular insufficiency impairs functional capacity in patients with heart failure
}

\author{
Insuficiência vascular periférica compromete a capacidade funcional no \\ paciente com insuficiência cardíaca
}

\author{
Renato Murayama', Laura Dutra Carraro', Thalissa Galvanin'1, Nilo Mitsuru Izukawa², \\ Iracema Umeda', Mayron Faria Oliveira',3
}

\begin{abstract}
Introduction: Heart failure (HF) is a complex syndrome in which effort limitation is associated with deterioration of peripheral musculature. Improving survival rates among these patients have led to the appearance of cases in which other pathologies are associated with HF, such as peripheral vascular insufficiency (PVI). The combination of these two pathologies is common, with significant repercussions for affected patients. Objective: To compare functional limitations and quality of life between patients with HF in isolation or HF + PVI. Method: Twelve patients with HF+PVI were paired to 12 patients with HF in isolation. All had ejection fraction $<40 \%$. The following were conducted: 6 minute walk test $(6 \mathrm{MWT})$, chair test (CT), step test (ST), one repetition maximum test (1RM) and quality of life questionnaire.

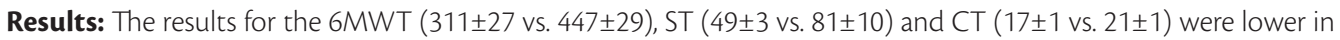
the HF+PVI group than in the HF group $(p<0.05)$. The HF+PVI group exhibited a reduction in the number of steps taken from the first to the second minute of the ST, in relation to the HF group. The HF group exhibited better HR recovery than the HF+PVI group ( $50 \pm 4$ vs. $26 \pm 3 ; \mathrm{p}<0.05$ ). No differences were found in results for the Borg scale, the peripheral muscle strength test $(1 R M)$ or the questionnaires $(p>0.05)$. Conclusions: The study participants who had mixed disease exhibited a greater degree of functional impairment than the group with HF, without reporting worsened quality of life.
\end{abstract}

Keywords: heart failure; peripheral vascular insufficiency; quality of life; 6-minute walk test; physiotherapy.

\begin{abstract}
Resumo
Introdução: A insuficiência Cardíaca (IC) é uma síndrome complexa e a limitação ao esforço está associada à piora da musculatura periférica. Devido à melhora na sobrevida destes pacientes, observa-se o surgimento de patologias associadas à IC, como a insuficiência vascular periférica (IVP). A associação das duas patologias é comum e com grandes prejuízos aos pacientes acometidos. Objetivo: Comparar as limitações funcionais e a qualidade de vida em IC isolada e IC + IVP. Método: Doze pacientes com IC+IVP foram pareados a 12 pacientes com IC isolada. Todos possuíam fração de ejeção <40\%. Foram realizados: teste da caminhada de seis minutos (TC6M), teste da cadeira (TCAD), teste do degrau (TD), teste de uma repetição máxima (1RM) e questionário de qualidade de vida. Resultados: Os valores

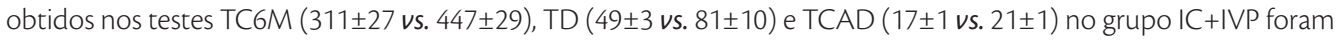
menores do que no grupo IC $(p<0,05)$, respectivamente. O grupo IC+IVP obteve redução do número de degraus alcançados entre o primeiro e o segundo minuto do TD em relação ao grupo IC. O grupo IC apresentou melhor

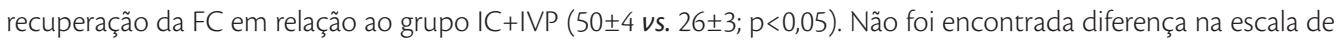
Borg, na força muscular periférica (1RM) e nos questionários aplicados ( $p>0,05)$. Conclusão: No presente estudo, os participantes com doença mista apresentaram maior comprometimento funcional em relação ao grupo com IC, sem demonstrar piora na qualidade de vida.
\end{abstract}

Palavras-chave: insuficiência cardíaca; insuficiência vascular periférica; qualidade de vida; teste de caminhada de seis minutos; fisioterapia.

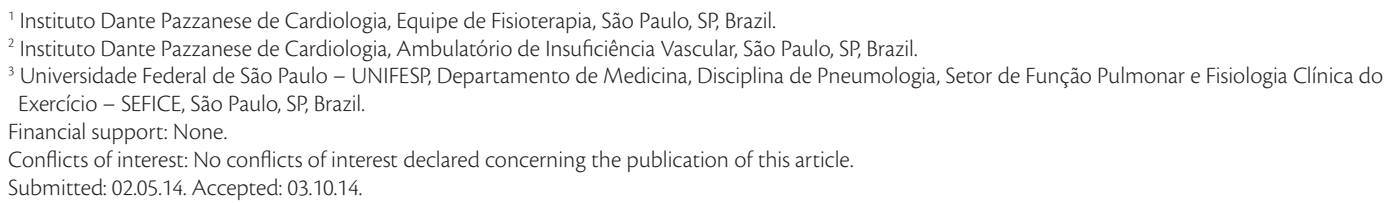

The study was carried out by the Physiotherapy and Medical Teams of the Vascular Insufficiency Service at Instituto Dante Pazzanese de Cardiologia, São Paulo-SP, Brazil. 


\section{INTRODUCTION}

Heart failure (HF) is a complex clinical syndrome of a systemic nature that is the common end stage of the majority of cardiovascular diseases and is characterized by neurohumoral exacerbation, skeletal myopathy and reduced functional capacity. ${ }^{1-5}$ It is an important public health problem with growing prevalence and hospital admission rates and is linked to high levels of morbidity and mortality. ${ }^{2-5}$ The syndrome can involve peripheral musculature and has a close relationship with exercise intolerance. ${ }^{6}$

With advances in medicine and drug therapies, HF is now seen in combination with other pathologies, which has an even greater negative impact on quality of life and the ability to perform daily activities. One pathology that is often found in combination with $\mathrm{HF}$ is peripheral vascular insufficiency (PVI) ${ }^{7}$ because of the many risk factors that the two pathologies have in common. In $90 \%$ of cases the reduced blood flow because of arterial obstruction has atherosclerotic origins. ${ }^{89}$ These types of obstruction are most frequently seen in the lower limbs and more than $20 \%$ of elderly populations can be affected.

The pathophysiology of PVI is related to an imbalance between circulatory delivery of nutrients and oxygen and the demand from skeletal musculature, which, in common with HF, causes functional impairment and changes to fiber types..$^{10,11}$ The reduction in oxygen delivery is also common to both pathologies ${ }^{12}$ and can provoke changes in muscle fiber types, while the chronic ischemic process can provoke structural and functional changes to the skeletal musculature. The compounded effects of risk factors - low cardiac output $\left(\mathrm{Q}_{\mathrm{T}}\right)$ and peripheral arterial occlusion - can reduce oxygen delivery to the muscles still further, potentially impacting on performance of daily activities, such as walking and going up and down stairs, in addition to having a negative impact on quality of life. The objective of the present study was therefore to compare functional limitations and quality of life in patients with HF only or HF and PVI.

\section{METHODS}

A total of 12 patients with Peripheral Vascular Insufficiency and Heart Failure (HF+PVI Group), aged 45 to 80 , were enrolled and paired for age and sex to 12 patients with HF alone (HF Group). The primary inclusion criterion for the study was sedentary patients with cardiomyopathy (ejection fraction $<40 \%$ ), previously confirmed by echocardiogram. Members of the HF+PVI group also had a diagnosis of unilateral or bilateral Peripheral
Arterial Occlusive Disease with limiting Intermittent Claudication (IC).

All patients were on medication optimized for $\mathrm{HF}$ and all members of the HF+PVI group had stable clinical status and were on specific medication for this pathology (Simvastatin, Aspirin or Ticlopidine, Cilostazol). Patients were excluded if they suffered from pain at rest and trophic lesions (Fontaine stages III and IV); had prior surgery; chronic obstructive pulmonary disease; or decompensated $\mathrm{HF}$; or if their clinical condition prevented them from performing the physiotherapeutic assessment tests or osteomuscular and/or neurological diseases that prevented them from performing the tests.

Each patient was provided with an Informed Consent Form that had been approved in advance by the Ethics Committee at the Instituto Dante Pazzanese de Cardiologia ( $n^{\circ}$ 9095). After they had signed the forms, patients underwent a physiotherapeutic assessment, and performed a 6-minute walk test (6MWT), a chair test (CT) a step test (ST) and one repetition maximum (1RM) tests for upper and lower limbs, and then answered the Minnesota quality of life questionnaire and an analog visual pain scale, and maximal inspiratory and expiratory pressure were measured.

\section{Six-minute walk test (6MWT)}

Tests were conducted in a 30-meter level corridor, delimited by two cones, as described by ATS criteria. ${ }^{13}$ Before the test, measurements were taken of arterial blood pressure (BP) (sphygmomanometer - Unilec ${ }^{\circledR}$ and stethoscope - Littmann Quality), heart rate $(\mathrm{HR})$ and peripheral oxygen saturation $\left(\mathrm{SpO}_{2}\right)$ (portable oximeter-OxiPlus ${ }^{\circledR}$ ) and the Modified Borg Scale of Perceived Exertion. ${ }^{14}$ The variables HR and $\mathrm{SpO}_{2}$ were monitored continuously throughout the test. All measurements were taken again at the end of the test and after a 2-minutes recovery period.

\section{Step test (ST)}

This test was conducted using a 'step' with a height of $20 \mathrm{~cm}$ and lasted 4 minutes, during which time the participant stepped up and back down at a velocity within their own limits. During the test, the tester provide verbal encouragement, employing a constant tone of voice, with the objectives of providing both encouragement and information on the participant's performance in the test. Heart rate and $\mathrm{SpO}_{2}$ were measured throughout the test. Blood pressure was measured and the Borg test conducted at the start and end of the test and after a 2-minute recovery period. 


\section{Chair test}

The chair test (CT) was conducted using a chair without arms. The participant was asked to sit on the center of the chair with their spine erect, feet shoulder-width apart and arms crossed across the chest and to rise and sit down as quickly as possible for one minute. The examiner recorded the number of times the participant managed to complete this movement. Heart rate and $\mathrm{SpO}_{2}$ were measured at the start of the test, at the end of the test and after a two-minute recovery period.

\section{Assessment of respiratory muscle strength}

Maximum respiratory pressures were acquired using digital vacuum manometer (MVD-300 V.1.1 Microhard System, Globalmed, Porto Alegre, Brazil), with an operating range of $\pm 300 \mathrm{cmH}_{2} \mathrm{O}$. For measurement of maximum inspiratory pressure $\left(\right.$ MAX $\left._{\text {IP }}\right)$, the patient was requested to perform a maximum inspiration, starting from residual volume. For measurement of maximum expiratory pressure $\left(\mathrm{MAX}_{\mathrm{EP}}\right)$, the patient was requested to perform a maximum expiration, starting from total lung capacity. Each patient performed five maximum inspirations and five maximum expirations, held for at least two seconds, the results of which had to be similar $(<10 \%$ difference), and the highest result of five was used for the analysis. All results were tested against equations for prediction of normal values. ${ }^{15}$

\section{Questionnaires}

The severity of HF was quantified for both groups using the quality of life questionnaire (Minnesota). ${ }^{16}$ Additionally, the mixed group (HF+PVI) also answered the Edinburgh Claudication questionnaire, for which each patient identifies the exact location of pain. Patients also quantified pain intensity using an Analog Visual Scale - AVS.

\section{One repetition maximum}

One repetition maximum (1RM) tests were used to assess the muscle strength of lower and upper limbs. All tests were conducted on the non-dominant side and dumbbells were used for arms and ankle weights for legs.

\section{Criteria for Termination of Tests}

If any patient suffered from unbearable pain in the limb affected by PVI, HF and/or PVI decompensation, heart rate $<50 \mathrm{bpm}$, dizziness, nausea, clouded vision, tingling feelings in the body, (systolic $\mathrm{BP}<80 \mathrm{mmHg}$ and diastolic $\mathrm{BP}<50 \mathrm{mmHg}$ ) or cold extremities, the test was terminated and the patient sent for medical examination.

\section{STATISTICAL ANALYSIS}

Initially, the Kolmogorov-Smirnov test was used to analyze data distribution. Student's $t$ test and the chi-square test were used for comparisons between the $\mathrm{HF}$ and $\mathrm{HF}+\mathrm{PVI}$ groups. Additionally, Pearson correlation coefficients were calculated for the variables analyzed. Differences were considered statistically significant if $\mathrm{p}<0.05$ for all analyses.

\section{RESULTS}

A total of 12 patients with HF in isolation and 12 patients with $\mathrm{HF}+\mathrm{PVI}$ were analyzed, all of them in NYHA functional class II. None of the patients had pacemakers and/or implantable cardioverterdefibrillator. No differences were detected between the two groups in terms of anthropometric variables, personal histories or medication, as can be observed in Table 1.

Table 1. Characteristics of patients studied.

\begin{tabular}{lcc}
\hline & $\begin{array}{c}\mathrm{HF} \\
(\mathrm{n}=12)\end{array}$ & $\begin{array}{c}\mathrm{HF}+\mathrm{PVI} \\
(\mathrm{n}=12)\end{array}$ \\
\hline Age (years) & $66 \pm 2$ & $67 \pm 2$ \\
Weight $(\mathrm{kg})$ & $73 \pm 4$ & $70 \pm 4$ \\
Height $(\mathrm{cm})$ & $165 \pm 2$ & $164 \pm 3$ \\
BMI $\left(\mathrm{kg} / \mathrm{m}^{2}\right)$ & $26 \pm 1$ & $26 \pm 1$ \\
History & & \\
Ex-Smoker & $7(58 \%)$ & $7(58 \%)$ \\
Smoker & $0(0 \%)$ & $3(25 \%)$ \\
AMI & $8(67 \%)$ & $3(25 \%)^{*}$ \\
SAH & $12(100 \%)$ & $7(58 \%)$ \\
DM & $4(33 \%)$ & $5(42 \%)$ \\
DLP & $10(83 \%)$ & $10(83 \%)$ \\
HF+CF & $2(17 \%)$ & $6(50 \%)^{*}$ \\
Diagnoses & & \\
Chagas CMP & $1(8 \%)$ & $\ldots$ \\
Ischemic CMP & $8(67 \%)$ & $10(80 \%)$ \\
Dilated CMP & $3(25 \%)$ & $2(20 \%)$ \\
PVI &.-- & $12(100 \%)$ \\
Medication & & $10(83 \%)$ \\
B-blocker & $11(92 \%)$ & $12(100 \%)$ \\
Diuretic & $12(100 \%)$ & \\
ACE-I & $11(92 \%)$ & \\
Cilostazol & - & $(85 \%)$ \\
\hline BMI-Body Mass & & \\
\hline
\end{tabular}

BMI - Body Mass Index; AMI - Acute Myocardial Infarction; SAH - Systemic Arterial Hypertension; DM - Diabetes Mellitus; DLP - Dyslipidemia; HF+CF - Family History Positive for Coronary Failure; CMP - Cardiomyopathy; PVI - Peripheral Vascular Insufficiency; B-blocker - Beta Blocker; ACE-I - Angiotensin-Converting Enzyme Inhibitor. *Statistically significant difference between groups $(p<0.05)$. 
Patients with mixed disease (HF+PVI) covered a significantly shorter distance in the 6MWT than patients in the HF group (Table 2). Additionally, five patients $(42 \%)$ in the HF+PVI group terminated the 6MWT because of fatigue and/or pain in the lower limbs, whereas none of the patients in the HF group needed to terminate the test $(\mathrm{p}<0.05)$. It was also observed that total number of steps taken in the ST and number of repetitions in the CT were both significantly lower for the group with mixed disease. Additionally, six patients (50\%) in the HF+PVI group terminated the ST because of fatigue and/or pain in the lower limbs, compared to two patients (17\%) in the HF group $(\mathrm{p}<0.05)$ who terminated the step test (Table 2). Furthermore, the HF+PVI group did not only manage a lower total number of steps, but, as shown in Figure 1, these patients also exhibited a considerable reduction in the number of steps taken from the first to the second minute, reducing gradually over time, which was not observed in the group with HF in isolation.

Peak HR during the clinical tests was higher in the HF+PVI group, but the difference was not statistically significant (Table 2). Notwithstanding,

Table 2. Variables analyzed for both groups.

\begin{tabular}{|c|c|c|}
\hline & $\mathrm{HF}(n=12)$ & $\mathrm{HF}+\mathrm{PVI}(\mathrm{n}=12)$ \\
\hline \multicolumn{3}{|l|}{ 6MWT } \\
\hline Distance (m) & $447 \pm 29$ & $311 \pm 27^{*}$ \\
\hline Peak Borg Dyspnea & $4 \pm 1$ & $3 \pm 1$ \\
\hline Peak Borg LL & $4 \pm 1$ & $5 \pm 1$ \\
\hline Peak HR (bpm) & $102 \pm 3$ & $105 \pm 5$ \\
\hline Test terminated & 0 & $5(42 \%)^{*}$ \\
\hline \multicolumn{3}{|l|}{ Chair test } \\
\hline Repetitions & $21 \pm 1$ & $17 \pm 1^{*}$ \\
\hline Peak Borg Dyspnea & $3 \pm 1$ & $2 \pm 1$ \\
\hline Peak Borg LL & $3 \pm 1$ & $3 \pm 1$ \\
\hline Peak HR (bpm) & $96 \pm 4$ & $102 \pm 5$ \\
\hline \multicolumn{3}{|l|}{ Step test } \\
\hline Total number of steps & $81 \pm 10$ & $49 \pm 3^{*}$ \\
\hline Peak Borg Dyspnea & $4 \pm 1$ & $4 \pm 1$ \\
\hline Peak Borg LL & $5 \pm 2$ & $7 \pm 1$ \\
\hline Peak HR (bpm) & $121 \pm 11$ & $124 \pm 13$ \\
\hline Test terminated & $2(17 \%)$ & $6(50 \%)^{*}$ \\
\hline \multicolumn{3}{|l|}{ Questionnaire } \\
\hline Minnesota & $32 \pm 6$ & $29 \pm 7$ \\
\hline Borg Scale & $\ldots$ & $6 \pm 1$ \\
\hline \multicolumn{3}{|l|}{1 Repetition Maximum } \\
\hline UL (Kg) & $5 \pm 1$ & $6 \pm 2$ \\
\hline $\mathrm{LL}(\mathrm{Kg})$ & $9 \pm 1$ & $8 \pm 7$ \\
\hline
\end{tabular}

6MWT - 6-Minute Walk Test; CT - Chair Test; ST - Step Test; Borg - Modified Borg Scale; LL - Lower Limbs; UL - Upper Limbs; Kg - Kilograms; bpm - Beats Per Minute. *Statistically significant difference between groups $(p<0.05)$. the change $(\Delta)$ in HR in the second minute of recovery ( $\Delta$ HR Peak - Recovery) from the ST was significantly higher in the group with $\mathrm{HF}$ in isolation than in the mixed group ( $50 \pm 4$ vs. $26 \pm 3 ; \mathrm{p}<0.05)$, respectively. We also observed that $\Delta \mathrm{HR}$ was higher in the HF only group for the 6MWT and the CT, but the differences in comparison with the HF+PVI group were not significant (Figure 2). No differences were detected between the HF and HF+PVI groups for the variables $\operatorname{MAX}_{\mathrm{IP}}(88 \pm 10$ vs. $79 \pm 29$, respectively) or $\operatorname{MAX}_{\mathrm{EP}}(99 \pm 14$ vs. $128 \pm 27$, respectively). The values of $\mathrm{MAX}_{\mathrm{IP}}$ and $\mathrm{MAX}_{\mathrm{EP}}$ were corrected for the percentages projected for the Brazilian population and once more no differences were found between the groups $(p>0.05)$. There were also no significant

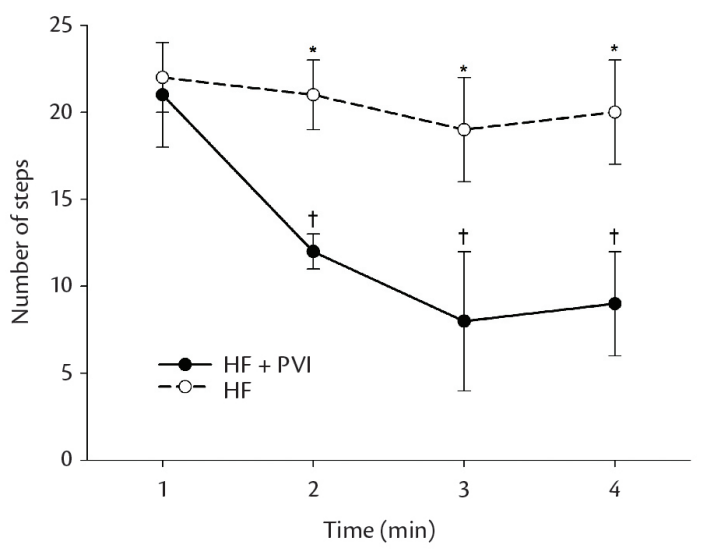

Figure 1. Comparison between groups of number of steps climbed during the test. HF Only Group (unshaded circle/ broken line) and HF+PVI group (shaded circle/unbroken line). Figures are expressed as mean \pm SD. Notes: ${ }^{*} p<0.05$; significant difference between $\mathrm{HF}$ and $\mathrm{HF}+\mathrm{PVI}$. $+\mathrm{p}<0.05$; difference compared to first minute.

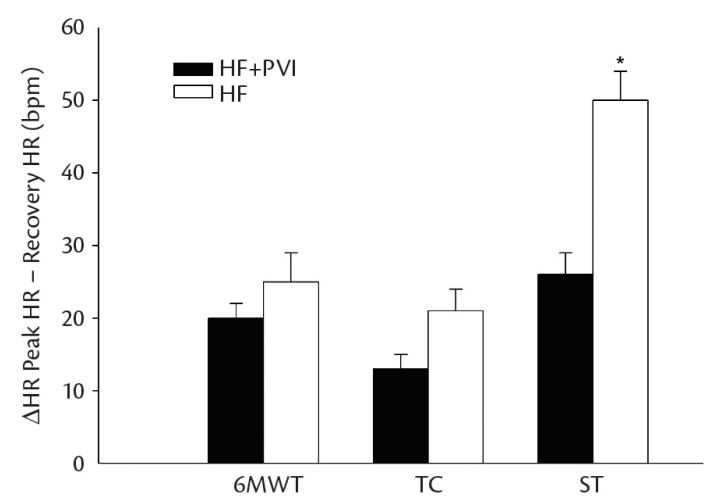

Figure 2. Comparison between HF group (unshaded bars) and $\mathrm{HF}+\mathrm{PVI}$ group (shaded bars) for $\triangle \mathrm{HR}$ (Peak HR - Recovery $H R$ ) during clinical tests. Figures are expressed as mean $\pm S D$. Note: ${ }^{*}<<0.05$; significant difference between HF and HF+PVI. 
differences observed for the Borg scale results at peak during the tests, for peripheral muscle strength (1RM) or for the results of questionnaires administered to both groups ( $\mathrm{p}>0.05)$.

\section{DISCUSSION}

The objective of this study was to compare functional limitations and quality of life in patients with $\mathrm{HF}$ in isolation and patients with both HF and PVI. Patients with mixed disease (HF+PVI) had greater functional deficits, with lower results for the 6MWT, CT and ST than patients with HF in isolation. It was also observed that $\Delta \mathrm{HR}$ (peak - recovery) was lower in the HF+PVI Group.

Some studies have suggested that the chronic ischemic process to which peripheral muscles are subjected can lead to reduced muscle strength and resistance among patients with PVI; these, in turn, tend to trigger further unfavorable mechanisms, leading to changes to the muscular phenotype. ${ }^{12,17,18}$ Another important factor in patients with PVI is the presence of pain in areas distal to damage caused by ischemia provoked by the pathology itself ${ }^{19}$ and, as a result, these patients tend to have lower physical activity levels and impaired walking capacity, all of which results in a general process of loss of fitness, inactivity and worsened quality-of-life. ${ }^{20}$

Arterial damage may be exacerbated by the abnormal hemodynamic response, chronic venous insufficiency or heart failure; it was notable that patients with PVI achieved shorter distances in the 6MWT than patients with HF alone. Although the results for quality of life were not different between the groups, it can be observed that in the present study day-to-day activities, represented by the 6MWT, CT and ST, were impaired for patients with HF+PVI. We believe that histological abnormalities in skeletal muscle of HF patients, such as muscle atrophy and reduced mitochondrial density, ${ }^{21-23}$ may have impacted these patients' capacity for microvascular $\mathrm{O}_{2}$ extraction. This in turn suggests that the patients with mixed disease suffer greater musculoskeletal compromise, leading to lower tolerance of exercise, as observed in the clinical tests.

Studies have shown that ergoreflex activity is exacerbated in HF patients, meaning that they exhibit abnormal HR responses..$^{5}$ Exacerbation of this mechanism could have caused the mixed group to reach higher peak HR during the tests than the HF group, but this effect was not observed in the present study, which was probably the result of the small number of patients. We believe that the pain provoked by arterial obstruction made a greater contribution to limitation of exercise and termination of the tests, meaning that the cardiovascular capacity of this group was underestimated.

The greater time taken for HR to recover in patients with HF is related to increased sympathetic activity. ${ }^{24,25}$ The pathophysiology of PVI leads us to believe that there may also be exacerbation of ergoreflex and of sympathetic activity in these patients, indicated by the observation of elevated HR recovery time in the mixed group. Significant differences in HR variability have already been demonstrated in heart patients with PVI. ${ }^{26}$ This abnormality of autonomic regulation could be interpreted as a compensatory mechanism for the reduced vasodilator capacity of arterioles seen in PVI.

According to Fick's equation $\left[\mathrm{VO}_{2}=\mathrm{Q}_{\mathrm{T}} \times\right.$ $\operatorname{dif}\left(\mathrm{a}-\mathrm{vO}_{2}\right)$ ], oxygen consumption $\left(\mathrm{VO}_{2}\right)$ can be limited by the capacity to supply or by the ability to use $\mathrm{O}_{2}$ (central mechanisms [convective] and peripheral mechanisms [diffusive]). It has already been demonstrated that the velocity with which $\mathrm{Q}_{\mathrm{T}}$ increases is compromised in patients with $\mathrm{HF}$ and, as a result, $\mathrm{O}_{2}$ supply to tissues is also reduced in these patients, further compromising peripheral musculature. ${ }^{27} \mathrm{We}$ believe that the combination of HF with PVI compromises this mechanism even further (the combination of reduced central supply and peripheral obstruction), thereby consuming all available $\mathrm{O}_{2}$ and, probably, using anaerobic metabolic pathways to enable exercise to continue. This effect may be attenuated when drugs to promote peripheral vasodilation are used, such as, for example sildenafil. ${ }^{28}$ The improvement in nitric oxide bioavailability to peripheral musculature improves the delivery/utilization imbalance during exercise and accelerates $\mathrm{VO}_{2}$ kinetics, with positive effects on exercise tolerance in patients with HF. If we take the peripheral arterial occlusion seen in patients with HF+PVI into consideration, the possibility of endothelial dysfunction and reduced nitric oxide production would explain the reduced functional capacity observed among these patients in the present study.

\section{LIMITATIONS TO THE STUDY}

The present study suffers from certain limitations, which should be taken into consideration:

- Small number of patients;

- No validation of the step test as a method of evaluating patients with heart failure and peripheral vascular insufficiency;

- No measurement of $\mathrm{VO}_{2}$ during the tests;

- No measurement of lactate;

- Tests not conducted in duplicate. 


\section{CONCLUSIONS}

We conclude that the group of patients with mixed disease (HF+PVI) exhibited similar quality-of-life and muscle strength, both respiratory and peripheral, to the patients with HF in isolation. However, the mixed disease group exhibited a decline in functional capacity and in the ability to perform daily activities, when compared with the group with HF alone. Although there is scant literature on cases of HF in combination with PVI, the importance of conducting further studies to compare functional impairment between these groups of patients is clear.

\section{REFERENCES}

1. Raposo L, Aguiar C, Ferreira J, Gonçalves PA, Ferreira A, Silva JA. Myocardial revascularization reverses adverse outcome in nonST-elevation acute coronary syndromes complicated by heart failure. Rev Port Cardiol. 2010;29(7-8):1131-42. PMid:21066967.

2. Fiuza M. Metabolic syndrome and coronary artery disease. Rev Port Cardiol. 2012;31(12):779-82. PMid:23138050. http://dx.doi. org/10.1016/j.repc.2012.09.005

3. Bocchi EA, Braga FG, Ferreira SM, et al. III Brazilian Guidelines on Chronic Heart Failure. Arq Bras Cardiol. 2009;93(1):3-70. PMid:20963312.

4. Bui AL, Horwich TB, Fonarow GC. Epidemiology and risk profile of heart failure. Nat Rev Cardiol. 2011;8(1):30-41. PMid:21060326 PMCid:PMC3033496. http://dx.doi.org/10.1038/ nrcardio.2010.165

5. Ribeiro F, Alves AJ, Teixeira $M$, et al. Exercise training enhances autonomic function after acute myocardial infarction: a randomized controlled study. Rev Port Cardiol. 2012;31(2):13541. PMid:22226329. http://dx.doi.org/10.1016/j.repc.2011.12.009

6. Richardson TE, Kindig CA, Musch TI, Poole DC. Effects of chronic heart failure on skeletal muscle capillary hemodynamics at rest and during contractions. J Appl Physiol. 2003;95(3):1055-62. PMid:12740313.

7. Hebert K, Lopez B, Michael C, et al. The prevalence of peripheral arterial disease in patients with heart failure by race and ethnicity. Congest Heart Fail. 2010;16(3):118-21. PMid:20557331. http:// dx.doi.org/10.1111/j.1751-7133.2010.00140.x

8. Bradberry JC. Peripheral arterial disease: pathophysiology, risk factors, and role of antithrombotic therapy. J Am Pharm Assoc. 2004;44(2):S37-44. http://dx.doi. org/10.1331/154434504322904596

9. Hilleman DE. Management of peripheral arterial disease. Am J Health Syst Pharm. 1998;55(19):S21-7. PMid:9784799.

10. McGuigan MR, Bronks R, Newton RU, et al. Muscle fiber characteristics in patients with peripheral arterial disease. Med Sci Sports Exerc. 2001;33(12):2016-21. http://dx.doi. org/10.1097/00005768-200112000-00007

11. Askew CD, Green S, Walker PJ, et al. Skeletal muscle phenotype is associated with exercise tolerance in patients with peripheral arterial disease. J Vasc Surg. 2005;41(5):802-7. PMid:15886664. http://dx.doi.org/10.1016/j.jvs.2005.01.037

12. Sharma R, Davidoff MN. Oxidative stress and endothelial dysfunction in heart failure. Congest Heart Fail. 2002; 8(3):165-72. http://dx.doi.org/10.1111/j.1527-5299.2002.00714.x

13. American Thoracic Society. ATS statement: guidelines for the sixminute walk test. Am J Respir Crit Care Med. 2002;166(1):111-7. PMid:12091180. http://dx.doi.org/10.1164/ajrccm.166.1.at1102
14. Borg GA. Psychophysical bases of perceived exertion. Med Sci Sports Exerc. 1982;14(5):377-81. PMid:7154893. http://dx.doi. org/10.1249/00005768-198205000-00012

15. Neder JA, Andreoni S, Lerario MC, Nery LE. Reference values for lung function tests. II. Maximal respiratory pressures and voluntary ventilation. Braz J Med Biol Res. 1999;32(6):719-27. http://dx.doi.org/10.1590/S0100-879X1999000600007

16. Carvalho VO, Guimarães GV, Carrara D, Bacal F, Bocchi EA Validation of the Portuguese version of the minnesota living with heart failure questionnaire. Arq Bras Cardiol. 2009;93(1):39-44. http://dx.doi.org/10.1590/S0066-782X2009000700008

17. Mitchell RG, Duscha BD, Robbins JL, et al. Increased levels of apoptosis in gastrocnemius skeletal muscle in patients with peripheral arterial disease. Vasc Med. 2007;12(4):285-90. PMid:18048464. http://dx.doi.org/10.1177/1358863X07084858

18. McDermott MM, Guralnik JM, Albay M, Bandinelli $S$, Miniati B, Ferrucci L. Impairments of muscles and nerves associated with peripheral arterial disease and their relationship with lower extremity functioning: the InCHIANTI Study. J Am Geriatr Soc. 2004;52(3):405-10. http://dx.doi. org/10.1111/j.1532-5415.2004.52113.x

19. Laghi Pasini F, Pastorelli M, Beermann U, et al. Peripheral neuropathy associated with ischemic vascular disease of the lower limbs. Angiology. 1996;47(6):569-77. http://dx.doi. org/10.1177/000331979604700605

20. Stewart KJ, Hiatt WR, Regensteiner JG, Hirsch AT. Exercise training for claudication. N Engl J Med. 2002; 347(24):1941-51. PMid:12477945. http://dx.doi.org/10.1056/NEJMra021135

21. Belardinelli R, Georgiou D, Cianci G, Purcaro A. 10-year exercise training in chronic heart failure: a randomized controlled trial. J Am Coll Cardiol. 2012;60(16):1521-28. PMid:22999730. http:// dx.doi.org/10.1016/j.jacc.2012.06.036

22. Drexler H, Riede U, Münzel T, König H, Funke E, Just H. Alterations of skeletal muscle in chronic heart failure. Circulation 1992;85(5):175159. http://dx.doi.org/10.1161/01.CIR.85.5.1751

23. Piepoli MF, Kaczmarek A, Francis DP, et al. Reduced peripheral skeletal muscle mass and abnormal reflex physiology in chronic heart failure. Circulation. 2006;114(2):126-34. PMid:16818813. http://dx.doi.org/10.1161/CIRCULATIONAHA.105.605980

24. Ponikowski PP, Chua TP, Francis DP, Capucci A, Coats AJ, Piepoli MF. Muscle ergoreceptor overactivity reflects deterioration in clinical status and cardiorespiratory reflex control in chronic heart failure. Circulation. 2001;104(19):2324-30. http://dx.doi. org/10.1161/hc4401.098491

25. Lahiri MK, Kannankeril PJ, Goldberger JJ. Assessment of autonomic function in cardiovascular disease: physiological basis and prognostic implications. J Am Coll Cardiol. 2008;51(18):172533. PMid:18452777. http://dx.doi.org/10.1016/j.jacc.2008.01.038

26. Goernig $M$, Schroeder R, Roth T, et al. Peripheral arterial disease alters heart rate variability in cardiovascular patients. Pacing Clin Electrophysiol. 2008;31(7):858-62. PMid:18684283. http://dx.doi. org/10.1111/j.1540-8159.2008.01100.x

27. Sperandio PA, Borghi-Silva A, Barroco A, Nery LE, Almeida DR, Neder JA. Microvascular oxygen delivery-to-utilization mismatch at the onset of heavy-intensity exercise in optimally treated patients with CHF. Am J Physiol Heart Circ Physiol. 2009;297(5):H1720-8 PMid:19734359. http://dx.doi.org/10.1152/ajpheart.00596.2009

28. Sperandio PA, Oliveira MF, Rodrigues MK, et al. Sildenafil improves microvascular $\mathrm{O} 2$ delivery-to-utilization matching and accelerates exercise $\mathrm{O} 2$ uptake kinetics in chronic heart failure. Am J Physio Heart Circ Physiol. 2012;303(12):H1474-80. PMid:23023868. http://dx.doi.org/10.1152/ajpheart.00435.2012 
Correspondence Mayron Faria Oliveira

Equipe de Fisioterapia, Instituto Dante Pazzanese de Cardiologia Av. Dr Dante Pazzanese, 500 - Vila Mariana

CEP 04012-180 - São Paulo (SP), Brazil Tel. : 55 (11) 5085-6304

E-mail:mayronfaria@hotmail.com

Author information

RM, LDC e TG são Fisioterapeutas Especialistas em Reabilitação Cardiovascular pelo/do Instituto Dante Pazzanese de Cardiologia. NMI é Médico-Chefe da Seção de Cirurgia Vascular do Instituto Dante Pazzanese de Cardiologia e Doutorado em Medicina pela Universidade de São Paulo (USP).

IU é Fisioterapeuta-Chefe da Equipe de Fisioterapia do Instituto Dante Pazzanese de Cardiologia e Mestre em Saúde Pública pela Universidade de São Paulo (USP).

MFO é Preceptor da Especialização na Reabilitação Cardiovascular da Equipe de Fisioterapia do Instituto Dante Pazzanese de Cardiologia, Mestre em Medicina Translacional pela Universidade Federal de São

Paulo (UNIFESP) e Doutorando no Setor de Função Pulmonar e Fisiologia Clínica do Exercício (SEFICE), Disciplina de Pneumologia,

Departamento de Medicina, Universidade Federal de São Paulo

(UNIFESP).

Author contributions

Conception and design: MFO, NMI, IU Analysis and interpretation: RM, LDC, TG, NMI, IU, MFO

Data collection: RM, LDC, TG

Writing the article: RM, LDC, TC

Critical revision of the article: MFO, NMI, IU

Final approval of the article*: MFO, RM, LDC, TG, NMI, IU Statistical analysis: MFO Overall responsibility: MFO Obtained funding: None.

* All authors have read and approved of the final version of the article submitted to J Vasc Bras. 